\title{
PEMBUATAN DAN UJI ORGANOLEPTIS SEDIAAN BEDAK DINGIN DARI JAGUNG MANIS (Zea mays Sacchrata) DAN TEPUNG BERAS (Oriza sativa L)
}

\author{
Bunga Delima Pramesti ${ }^{1}$, Reti Puji Handayani ${ }^{2 *}$, Sitti Sarah Nuraini ${ }^{3}$ \\ 1,2,3 Sekolah Tinggi Ilmu Kesehatan Holistik \\ *Korespondensi: Jl. Veteran No.272 Ciseureuh Purwakarta, Email: retipunya@gmail.com
}

\begin{abstract}
ABSTRAK
Latar Belakang: Jerawat merupakan masalah kulit yang hampir melanda setiap orang, namun penggunaan produk perawatan wajah yang mengandung bahan-bahan kimia tidak bisa dihindari.

Tujuan Penelitian: Penelitian ini bertujuan untuk membuat sediaan bedak dingin dan mengetahui stabilitas sediaan bedak dingin dari jagung manis (Zea mays Sacharata) dan beras (Oryza sativa L.) selama 3 minggu.

Metode: Penelitian ini menggunakan desain penelitian tindakan ujicoba formulasi dua pelarut yang berbeda.

Hasil: Hasil penelitian menunjukan bahwa sampel dengan pelarut aquadest tidak terdapat perubahan warna, aroma serta stabil dalam masa penyimpanan tiga minggu. Hasil pengujian $\mathrm{pH}$ memenuhi persyaratan $\mathrm{pH}$ untuk wajah yaitu 4-6. Sedangkan untuk sediaan dengan pelarut air mawar yang mengandung oleum rosae cenderung lebih lembab karena mengandung minyak yang lebih susah menguap sehingga terjadi perubahan warna, bau, $\mathrm{pH}$ dan muncul jamur.

Simpulan: Dari hasil penelitian disimpulkan bahwa pembuatan sediaan dengan pelarut aquadest lebih stabil, warna tidak berubah, aroma khasnya, pH stabil dan tidak ditemukan jamur selama penyimpanan tiga minggu. Disarankan untuk melakukan penelitian lebih lanjut dengan waktu pengeringan yang lebih lama.
\end{abstract}

Kata kunci: bedak dingin, jagung, tepung beras

\begin{abstract}
Background: Acne is a skin problem that almost struck any person, however, the use of skin care products containing chemicals can not be avoided.

objective: This study aims to make dosage cold powder and determine the stability of the dosage cold powder of sweet corn (Zea mays Sacharata) and rice (Oryza sativa L.) for 3 weeks.

Method: This study uses action research design testing the formulation of two different solvents.

Result: The results showed that the samples with the solvents distilled water there is no change in color, scent as well as stable in the storage period of three weeks. The results of $\mathrm{pH}$ testing meet the requirements of the $\mathrm{pH}$ to the face is 4-6. As for dosage forms with solvents of rose water containing oleum rosae tend to be more moist because it contains oil which is harder to evaporate so that changes in color, odor, $\mathrm{pH}$ and appear fungus.

Conclusion: From the results of the study concluded that the manufacture of dosage forms with the solvents distilled water is stable, no color change, scent trademark, $p H$ stable and not found the mushrooms during storage for three weeks. It is recommended to do more research with the drying time is longer.
\end{abstract}

Keywords: cold powder, corn, rice flour

\section{PENDAHULUAN}

Kulit wajah yang bersih, cerah, halus dan terbebas dari jerawat sangat diinginkan oleh setiap orang. Namun sekarang ini hampir setiap orang memiliki masalah jerawat. Di Indonesia sekitar 95-100\% lakilaki maupun $83-85 \%$ perempuan usia 16-17 tahun pernah mengalami masalah jerawat dengan pravelansi jerawat pada perempuan dewasa sekitar $12 \%$ sedangkan pada lakilaki dewasa berkisar 3\%. Dalam suatu penelitian lain didapatkan bahwa jerawat merupakan masalah kulit sampai melewati masa remaja dengan prevalensi perempuan lebih tinggi dibandingkan laki-laki pada rentang usia 20 tahun atau lebih. ${ }^{1}$ 
Menurut Muliyawan dan Suriana, jerawat adalah reaksi dari penyumbatan pori-pori kulit disertai peradangan yang bermuara pada saluran kelenjar minyak kulit. Sekresi minyak kulit menjadi tersumbat, membesar dan akhirnya mongering menjadi jerawat. ${ }^{2}$ Jerawat yang muncul dibagian muka sering mengakibatkan perubahan wajah dan menimbulkan bekas wajah yang sulit dihilangkan. Salah satu penanganan masalah jerawat adalah dengan menggunakan produk perawatan wajah. Namun penggunaan produk perawatan wajah yang beredar dipasaran banyak mengandung bahan-bahan yang berpotensi membahayakan kesehatan kulit wajah. Zat kimia yang sering ditambahkan dalam kosmetik adalah hidrokuinon dan merkuri karena kemampuan zat tersebut untuk menghambat pembentukan melanin pada permukaan kulit dan menjadikan kulit mulus dalam jangka waktu yang relatif singkat. ${ }^{3}$

Hasil penggunaan produk perawatan wajah yang mengandung zat kimia dapat terlihat cepat tetapi tidak aman dalam pemakaian jangka panjang. Saat ini terdapat pilihan produk perawatan wajah yang terbuat dari bahan alami yaitu jagung manis. Sugeng menyatakan bahwa kandungan yang terdapat pada jagung diantaranya thiamin yang dapat mengeringkan luka/noda-noda. ${ }^{4}$ Dalam jurnal Karmilah (2018) dan Nining (2014) dinyatakan bahwa jagung memiliki kandungan vitamin A, B dan E yang bersifat sebagai antioksidan yang sangat bermanfaat menangkal radikal bebas, mencegah penuaan dini, serta kandungan prokaroten (protein, karbohidrat dan sedikit lemak) yang dapat memperbaiki struktur kulit. Selain itu, zat yang ada di dalam jagung juga membantu mengatasi munculnya jerawat tanpa membuat wajah jadi lebih berminyak atau kering, jagung.4,5

Berdasarkan uraian tersebut maka penulis tertarik untuk membuat sediaan bedak dingin yang berbahan alami yang terbuat dari campuran jagung (Zea mays Saccharata ) dan beras (Oryza sativa L.) untuk perawatan wajah, yang praktis mudah dibawa dan sekaligus untuk memperkenalkan kepada masyarakat bahwa jagung bisa digunakan sebagai perawatan wajah untuk mengobati bekas jerawat. Penelitian dilakukan dengan mengamati stabilitas sediaan secara organoleptik yang mencakup konsistensi sediaan, warna, bau, rasa, dan pertumbuhan jamur pada sediaan dengan membuat dua formulasi menggunakan variasi pelarut, formulasi satu menggunakan pelarut air mawar dan formulasi dua menggunakan pelarut air biasa.

\section{METODE PENELITIAN}

Jenis penelitian yang digunakan adalah penelitian tindakan dengan melakukan uji coba formulasi menggunakan desain penelitian komparatif dengan membandingkan variasi pelarut pada setiap perlakuan sampel. Penelitian tindakan yaitu suatu rangkaian mulai dari perencanaan, pelaksanaan, pengamatan, refleksi dan perencanaan kembali untuk suatu ancangancang pemecahan masalah. ${ }^{6}$ Spesimen tumbuhan jagung manis (Zea mays Sacchrata) pada penelitian ini diperoleh langsung dari desa Gempolsari, Subang. Penelitian ini dilakukan dengan membagi sampel kedalam dua kelompok berdasarkan variasi pelarut yang digunakan. Masingmasing kelompok diuji dalam dua kondisi penyimpanan, yaitu suhu sejuk $15^{\circ} \mathrm{C}$ dan pada suhu ruang $25^{\circ} \mathrm{C}$. Sediaan bedak dingin dibuat dari bahan tepung jagung dan tepung beras. Jagung yang sudah bersih kemudian diparut lalu diperas untuk diendapkan kemudian diambil patinya.

Sedangkan pada beras dicuci bersih kemudian direndam semalaman agar teksturnya lebih lunak ketika diblender. Setelah direndam beras ditiriskan kemudian diblender halus hingga menjadi tepung beras. Tepung beras dan tepung jagung ditimbang untuk pembuatan sampel bedak dingin. Formulasi sampel I dengan pelarut air mawar dibuat dengan membuat adonan homogen 30 gram tepung jagung dan 25 gram tepung beras lalu dibuat bulatan kecil kemudian dijemur hingga kering. Formulasi sampel II dengan pelarut aquadest dibuat dengan komposisi berat bahan yang sama kemudian diamati dan diteliti selama tiga minggu. Parameter yang diamati pada penelitian ini yaitu uji 
organoleptik meliputi warna, bau, rasa, dan bentuk sediaan.

HASIL PENELITIAN
Berdasarkan penelitian yang dilakukan selama tiga minggu didapatkan hasil sebagai berikut :

Tabel 1. Uji organoleptik pelarut air mawar

\begin{tabular}{|c|c|c|c|c|c|c|c|c|c|}
\hline \multirow{2}{*}{$\begin{array}{c}\text { Sampel } \\
\text { I }\end{array}$} & \multirow[t]{2}{*}{ Pengamatan } & \multicolumn{8}{|c|}{ Hari ke } \\
\hline & & 1 & 3 & 6 & 9 & 12 & 15 & 18 & 21 \\
\hline \multirow[t]{4}{*}{$15{ }^{\circ} \mathrm{C}$} & Warrna & Putih & Putih & Putih & Putih & Putih & Putih & Putih & Putih \\
\hline & Bau & Khas & Tengik & Tengik & Tengik & Tengik & Tengik & Tengik & Tengik \\
\hline & Jamur & $\begin{array}{c}\text { Tidak } \\
\text { ada }\end{array}$ & Ada & Ada & Ada & Ada & Ada & Ada & Ada \\
\hline & $\mathrm{pH}$ & 4,4 & 6,1 & 6,1 & 6,3 & 6,3 & 6,4 & 6,4 & 6,4 \\
\hline \multirow[t]{4}{*}{$25{ }^{\circ} \mathrm{C}$} & Warna & Putih & Putih & Putih & $\begin{array}{c}\text { Bintik } \\
\text { hijau }\end{array}$ & Hijau & Hijau & $\begin{array}{l}\text { Hijau } \\
\text { pekat }\end{array}$ & $\begin{array}{l}\text { Hijau } \\
\text { Pekat }\end{array}$ \\
\hline & Bau & Khas & Khas & Tengik & Tengik & Tengik & Busuk & Busuk & Busuk \\
\hline & Jamur & $\begin{array}{c}\text { Tidak } \\
\text { ada }\end{array}$ & $\begin{array}{c}\text { Tidak } \\
\text { ada }\end{array}$ & Ada & Ada & Ada & Ada & Ada & Ada \\
\hline & $\mathrm{pH}$ & 4,4 & 5,2 & 5,4 & 5,4 & 6,4 & 7,4 & 8,4 & 8.6 \\
\hline
\end{tabular}

Tabel 2. uji organoleptik pelarut aquadest

\begin{tabular}{|c|c|c|c|c|c|c|c|c|c|}
\hline \multirow{2}{*}{ Sampel II } & \multirow{2}{*}{ Pengamatan } & \multicolumn{8}{|c|}{ Hari ke } \\
\hline & & 1 & 3 & 6 & 9 & 12 & 15 & 18 & 21 \\
\hline \multirow{4}{*}{$15^{\circ} \mathrm{C}$} & Warna & Putih & Putih & Putih & Putih & Putih & Putih & Putih & Putih \\
\hline & Bau & Khas & Khas & Khas & Khas & Khas & Khas & Khas & Khas \\
\hline & Jamur & $\begin{array}{c}\text { Tidak } \\
\text { ada }\end{array}$ & $\begin{array}{c}\text { Tidak } \\
\text { ada }\end{array}$ & $\begin{array}{c}\text { Tidak } \\
\text { ada }\end{array}$ & $\begin{array}{c}\text { Tidak } \\
\text { ada }\end{array}$ & $\begin{array}{c}\text { Tidak } \\
\text { ada }\end{array}$ & $\begin{array}{c}\text { Tidak } \\
\text { ada }\end{array}$ & $\begin{array}{c}\text { Tidak } \\
\text { ada }\end{array}$ & $\begin{array}{c}\text { Tidak } \\
\text { ada }\end{array}$ \\
\hline & $\mathrm{pH}$ & 4.3 & 5,4 & 5.4 & 5.4 & 5,5 & 5,6 & 6,0 & 6,0 \\
\hline \multirow{4}{*}{$25^{\circ} \mathrm{C}$} & Warna & Putih & Putih & Putih & Putih & Putih & Putih & Putih & Putih \\
\hline & $\mathrm{Bau}$ & Khas & Khas & Khas & Khas & Khas & Khas & Khas & Khas \\
\hline & Jamur & $\begin{array}{c}\text { Tidak } \\
\text { ada }\end{array}$ & $\begin{array}{c}\text { Tidak } \\
\text { ada }\end{array}$ & $\begin{array}{c}\text { Tidak } \\
\text { ada }\end{array}$ & $\begin{array}{c}\text { Tidak } \\
\text { ada }\end{array}$ & $\begin{array}{c}\text { Tidak } \\
\text { ada }\end{array}$ & $\begin{array}{c}\text { Tidak } \\
\text { ada }\end{array}$ & $\begin{array}{c}\text { Tidak } \\
\text { ada }\end{array}$ & $\begin{array}{c}\text { Tidak } \\
\text { ada }\end{array}$ \\
\hline & $\mathrm{pH}$ & 4,3 & 4.6 & 5,2 & 5,7 & 5,7 & 6,0 & 6,0 & 6,0 \\
\hline
\end{tabular}

\section{PEMBAHASAN PENELITIAN}

Penelitian ini dilakukan di laboratorium STIKes Holistik purwakarta pada bulan Juli 2018. Bahan yang digunakan dalam membuat sediaan bedak dingin adalah jagung manis dan beras. Pengamatan tiga hari sekali dilakukan terhadap dua sampel yang disimpan di tempat yang berbeda, antara lain meliputi warna, bau, jamur dan $\mathrm{pH}$. Perlakuan berbeda pada penyimpanan sediaan bedak dingin dimaksudkan untuk mengetahui tempat penyimpanan yang paling baik untuk sediaan bedak dingin dengan konsistensi yang baik.

Dari Tabel 1 terlihat bahwa uji organoleptis menggunakan pelarut air mawar pada penyimpanan baik suhu sejuk maupun suhu ruang terjadi perubahan warna, bau, pH dan muncul jamur. Hal ini menunjukkan bahwa sediaan bedak dingin dengan pelarut air mawar tidak stabil. Penyebabnya karena air mawar mengandung oleum oleum rosae yang cenderung lebih lembab dan karena minyak lebih susah menguap dibanding air maka mudah ditumbuhi jamur dan pengeringan sediaan hanya dilakukan satu hari sehingga sediaan tidak betul-betul kering dan mudah ditumbuhi mikroorganisme, selain itu air mawar memiliki $\mathrm{pH}$ yang cenderung asam. Dari hasil pengujian $\mathrm{pH}$ yang dilakukan dapat dilihat bahwa sediaan bedak dingin dengan pelarut air mawar tidak memenuhi persyaratan $\mathrm{pH}$ untuk wajah yaitu 4-6.

Pada hasil pengamatan uji organoleptis sampel II menggunakan pelarut aquadest dalam penyimpanan suhu sejuk terlihat bahwa tidak terjadi perubahan warna, baud an tidak ada jamur. Hasil pengamatan uji pH juga diperoleh perubahan yang cukup stabil. Sama halnya 
dengan pengamatan suhu ruangan, tidak tejadi perubahan warna, bau dan tidak ada jamur. Sehingga sampel II menunjukkan bahwa kondisi sediaan bedak dingin stabil dalam dua kondisi penyimpanan yang berbeda dan memenuhi persyaratan $\mathrm{pH}$ untuk wajah yaitu 4-6.

\section{SIMPULAN}

Berdasarkan hasil pengamatan dan analisis data yang dilakukan dapat ditarik kesimpulan bahwa sediaan bedak dingin yang dibuat dengan 2 perbandingan pelarut yaitu pelarut air mawar dan pelarut aquadest serta masing-masing sampel mendapat perlakuan penyimpanan dalam suhu sejuk dan suhu ruang. Sediaan bedak dingin dibuat dari pembuatan tepung jagung dan tepung beras dengan penambahan pelarut agar mudah dibentuk. Hasil pengamatan uji organoleptik dari perbandingan ke 2 pelarut, diperoleh bahwa sediaan dengan pelarut aquadest lebih stabil dari bentuk, warna tidak berubah, aroma khas yang stabil serta tidak ditemukannya jamur pada permukaan sediaan bedak dingin selama penyimpanan tiga minggu. Perbedaan tersebut dipengaruhi oleh sifat minyak dan aquadest yang berbeda.

\section{DAFTAR PUSTAKA}

1. Nurarif (2014). Jurnal Pengaruh Masker Jagung dan Minyak Zaitun terhadap Perawatan Kulit Wajah. Semarang

2. Dewi Muliyawan dan Neti Suriana. (2013). A-Z tentang Kosmetik. Jakarta: Elex Media Komputindo.

3. Syafnir.(2011).Pengujian Kandungan Merkuri Dalam Sediaan kosmetik dengan Spektrofotometri Serapan Atom.Prosidingsnapp 2011 Sains, Teknologi Dan Kesehatan ISSN:20893582.

4. Karmila. (2018). Teknologi Pangan : Teori Praktis dan Aplikasi.Yogyakarta: Graha Ilmu.

5. Nining.(2014). Jurnal Pengaruh Masker Jagung Dan Minyak Zaitun Terhadap Perwatan Kulit Wajah. Semarang.

6. Kurt Lewin (1946) Metode Penelitian Kuantitatif, Kualitatif, dan Penelitian Gabungan.Jakarta : Kencana. 